\title{
Anwar Ilbrahim's Struggle for the Real and Malaysian Politics in Transition
}

\author{
Jared Genser ${ }^{1}$, Sivarasa Rasiah ${ }^{2}$ \\ ${ }^{1}$ Founder of Freedom Now and international counsel to Liu Xiaobo \\ ${ }^{2}$ A prominent Malaysian politician, lawyer, human rights activist and a Malaysian writer
}

\section{Abstract}

This paper is about Anwar Ibrahim and politics in Malaysia. Anwar Ibrahim was born in a village near Penang, Malaysia on August 10, 1947. His parents were a hospital medical assistant and a housewife who became engaged in local grassroots politics early on. Anwar became involved in politics in 1971 as a pro-Islam student leader, founding the Muslim Youth Movement of Malaysia. He remained its president until 1982.67 Although he was a leader of opposition groups - in fact he was jailed under the Internal Security Act for two years for organizing mass demonstrations in 1974 - Anwar accepted an invitation in 1982 to join the ruling United Malays National Organization (UMNO). Rising quickly through the ranks of the party, he served in succession as the Minister of Culture, Youth, and Sports in 1983, of Agriculture in 1984, of Education from 1986-91, and was appointed Minister of Finance from 1991-98. In 1993, Anwar also became Deputy Prime Minister for Prime Minister Mahathir.68 He served as Deputy Prime Minister until 1998, when he was dismissed, on the pre-text of corruption and sodomy allegations, because of major disagreements with Mahathir about the political and economic direction of Malaysia's future.
Keywords

Anwar Ibahim sodomy charges,

Malaysia; leader, opposition

\section{Introduction}

Anwar Ibrahim, former Deputy Prime Minister of Malaysia and former political opposition leader, is serving a five-year sentence on fabricated sodomy charges. Anwar's infamous trial, which began in 2008 and concluded in February 2015, was replete with human rights violations and a lack of due process protections. Among them was a complete lack of credible evidence of the alleged act and blatant partiality in favor of the prosecution. In Malaysia, the trial was dubbed "Sodomy II" because, incredibly, Anwar was also accused and convicted on fabricated sodomy once before in 1998. As both cases are widely considered to be fabricated, it was also dubbed "Fitnah II," which in the local language means slander.

Despite systematic political persecution against him, Anwar has stayed active in politics throughout nearly all of his adult life. He served in succession as the Minister of Culture, Youth, and Sports in 1983, of Agriculture in 1984, of Education from 1986-91, and was appointed Minister of Finance from 1991-98. In 1993, Anwar also became Deputy Prime Minister for then Prime Minister Mahathir Mohamad, a position he held until 1998.

After he was released from prison in the first sodomy case in 2004, Anwar emerged as the leader of a new party dedicated to a unified Malaysia, not defined by race or religion, but 
dedicated to equality of opportunity, and economic and social justice. Anwar's party, the National Justice Party (later called the People's Justice Party), in coalition with other opposition parties, gained enough power and parliamentary seats in elections to threaten the establishment party, United Malays National Organization (UMNO), and current Prime Minister Najib Razak.

\section{Review of Literature}

Anwar's current detention starting in February 2015 is punishment for having exercised his fundamental human rights to freedom of opinion and expression, and political participation. Najib considers Anwar - and the promise of a democratic Malaysia he represents - to be a threat to his hold on power as the coalition led by Anwar won 51 percent popular support in the last general election. The fabricated sodomy charges are an attempt to silence Anwar and prevent him from participating in Malaysian politics.

The UN High Commissioner for Human Rights, the European Union and Parliament, the Inter-Parliamentary Union (IPU), Association of Southeast Asian Nations (ASEAN), Parliamentarians for Human Rights, Amnesty International, Human Rights Watch, the US Government, the UK Government, the Australian Government, and leading intellectual leaders, among others, have publically criticized Anwar's politically-motivated conviction; many have called for his immediate release. The UN Working Group on Arbitrary Detention (Working Group) found Anwar's detention to be arbitrary and in violation of international law, and also urged his immediate release.

To date, the conditions of Anwar's detention are extremely troubling. He suffers from a serious shoulder injury, and he is being denied adequate necessary medical treatment, which constitutes cruel, inhuman, and degrading treatment, and may amount to torture. This was noted in the Working Group's opinion and in an October 2015 statement by the InterParliamentary Union.

\section{Discussion}

\section{Malaysia and Najib's government}

Despite Malaysia's reputation as a moderate Muslim nation, the Malaysian Government has undertaken an intensifying crackdown on political opposition and dissent. When Najib Razak assumed office in 2009, there was hope that the country, which had been ruled by the same party since it gained independence from Britain in 1957, might be capable of making a true democratic transition. 2 Najib promised to eliminate preferences favoring ethnic Malays, reduce police powers, repeal a repressive anti-sedition law, and promote free and fair elections.

Despite these promises, Najib has overseen an increasing crackdown against his political opponents and on basic freedoms, which started in 2013 when the ruling Barisan Nasional (BN) coalition lost the popular vote to the multi-ethnic People's Alliance (Pakatan Rakyat or PR) coalition in national elections.4 His ruling party, United Malays National Organization (UMNO), part of the BN coalition, clung to power only through the gerrymandering of electoral boundaries.5 In the aftermath of the election, Najib launched a campaign aimed at crippling the opposition.6 Crackdowns on peaceful assembly, restrictions on the media, censorship of books and films, and targeting of ethnic and religious minorities have been on the rise since then.

Meanwhile, Najib's administration has also led Malaysia in a direction of increased Islamization. Senior leaders within Najib's UMNO party have openly supported calls for the 
implementation of Islamic criminal law, or hudud, from conservative Islamists in the north, 8 Najib himself has supported court bans on non-Muslims using the word "Allah,"9 and Najib's administration has developed a "Sharia Index" to measure how well the Government is complying with Islamic principles across legal, economic, political and social issues with the ultimate goal of making them aligning more closely. 10 This trend towards conservative and illiberal Islamization is worrying for the roughly one-third of the country's population who are non-Muslim. Najib has even showered praise on the Islamic State of Iraq and the Levant (ISIL or ISIS), saying that if UMNO members were as brave as ISIS militants, the party would be strong.

Najib has also initiated the return of overbroad security measures to try and repress political dissent. In April 2015, Najib promoted a new Prevention of Terrorism Act that gives the Government the right to detain terror suspects for at least two years, with the possibility of extensions and restriction of movement for five years.13 Additionally, instead of repealing the colonial-era Sedition Act as promised, he has strengthened it with even more draconian provisions - changing the penalty for sedition from a fine and the possibility of jail to a mandatory jail sentence of three to seven years, 14 and introducing a penalty of up to 20 years for seditious activities that result in physical harm or destruction of property. 15 Especially concerning are the amendments targeting publications, enabling the Government to prohibit any publication that "appears to be promoting feeling of ill will, hostility or hatred" between different social, ethnic, or religious groups.16 UN High Commissioner for Human Rights Zeid Ra'ad Al Hussein expressed concern over the amendments to the Sedition Act shortly before they passed, saying, "The UN Human Rights Office has long urged Malaysia to either repeal the 1948 Sedition Act or to bring it in line with international human rights standards...It is very disappointing that the Malaysian Government is now proposing to make a bad law worse."

Najib's government continues to intimidate and silence any opposition. In addition to his political strategy of dividing the opposition by encouraging conservative Islamic positions and aggravating racial and religious tensions, $18 \mathrm{Najib}$ has also made use of time-consuming legal distractions that significantly interfere with the political work of opposition leaders and tarnish reputations. For example, Anwar's daughter, Nurul Izzah Anwar, herself a Member of Parliament, was arrested on March 16, 2015 for sedition because of a speech she made in parliament that was critical of the judiciary and Anwar's conviction.19 Human Rights Watch called her arrest "another step towards the destruction of rights-respecting democracy in Malaysia."20 Over twenty elected representatives from the opposition parties now face either sedition or other criminal charges that may disqualify them from further political participation. These include two of Anwar's own lawyers, N. Surendran and Sivarasa Rasiah, also Members of Parliament, who were also charged for speeches criticizing Anwar's conviction.

Additionally, Section 124 of the Penal Code, a legal measure added to the Government's arsenal in March 2012, vaguely criminalizes any "activity detrimental to parliamentary democracy," making such offenses punishable by up to 20 years in prison.21 This new law lay dormant for 2 years, but is now being used to target and silence members of the opposition. It has been regularly used to threaten peaceful student protesters as well as the members of an investigation into corruption allegations against Najib.22 Additionally, the investigation into Anwar's daughter Nurul Izzah was also initially investigated under Section 124B in March 2015.23 It is estimated that, while at least 138 of these cases have been opened by Najib's administration in 2015 alone, not a single extremist or terrorist has been properly charged with the offense. 
Najib's opponents also face unique barriers to participating in political processes, as they are occasionally prohibited from campaigning in BN strongholds. On May 2, 2016, Nurul Izzah was barred from entering Sarawak, one of Malaysia's semiautonomous states, after attempting to campaign in the local election, an election described by Najib as a "precursor" of the next general election in 2018.25 Opposition Members of Parliament Tony Pua, Rafizi Ramli, and Teresa Kok were also barred from entering the state.26

This campaign of intimidation has also extended to Malaysian media outlets sympathetic to the opposition. In March 2015, three editors and two executives at The Malaysian Insider were arrested under the Sedition Act after the news site published an article about a proposal to allow strict enforcement of Islamic law.27 On April 3, 2015, cartoonist Zulkiflee Anwar Ulhaque, known as Zunar, was charged with nine counts of sedition for a series of tweets criticizing how the judiciary handled Anwar's case. 28 Most recently, on February 25, 2016, the Malaysian Communications and Multimedia Ministry blocked access to The Malaysian Insider's portal, such that those who tried to access the news site were met with the message: "The website is not available in Malaysia as it violate(s) the National law(s).29 It has since closed down as a direct impact of that Punitive action.

Najib has also employed these laws to attempt to silence critics on his 1Malaysia Development Berhad (1MDB Fund), which is $\$ 12$ billion in debt.31 1MDB is the government-owned investment and development company that was set up by Najib in 2009 to address "strategic development" in Malaysia. PKR politician Rafizi Ramli and Public Accounts Committee member Tony Pua are two of the people who have been targeted for merely attempting to do their jobs and hold the Government to account for the apparent mismanagement and misappropriation of funds of 1MDB.32 The former political secretary to the previous Prime Minister Dr. Mahathir Mohamad, Matthias Chang, was also jailed recently for defending a client who made reports of corruption at 1MDB.

Recent events involving the misuse of $1 \mathrm{MDB}$ funds became personal for Najib when a July 2015 Wall Street Journal article publicized that $\$ 700$ million of unaccounted money were found in Najib's personal accounts.34 Since that revelation, Najib has removed four high-ranking cabinet members, including his Deputy Prime Minister, and fired the Attorney General investigating the allegations of corruption.35 On October 8, 2015, Najib's new Attorney General went so far as to throw out the Central Bank's evidence of corruption at 1MDB. In February 2016, he shut down a major domestic investigation of the case by the Malaysian Anti-Corruption Commission.36 At the end of March 2016, it was revealed that Najib has spent approximately $\$ 15$ million on luxury items, which are believed to have been paid for with money originating from the 1MDB Fund.37 The Prime Minister's stepson, Riza Aziz, also allegedly spent over $\$ 50$ million from $1 \mathrm{MDB}$ to purchase luxury properties in New York and Beverly Hills, according to a May 12, 2016 report by The Wall Street Journal.38 One month after the Malaysian Parliament's bipartisan Public Accounts Committee released its April 2016 report criticizing the 1MDB advisory board's management of the fund and calling for the abolishment of the board, then headed by Najib, Malaysia's Finance Ministry dissolved the advisory board.39 In July 2016, the US Government filed a formal complaint to seize more than $\$ 1$ billion in assets purchased with 1MDB.40 In September 2016, it was confirmed that Najib was named, through a pseudonym, in that complaint.

Najib's frustration with the US Government's actions has led him to develop closer to ties with China.42 In an attempt to cover-up financial misconduct related to the 1MDB scandal, Najib and his cabinet reportedly struck a deal with the Chinese state company China Communications Construction Company to pay off over \$7 billion in debt in July 2016.43 Most recently, in early November 2016 Najib travelled to China to meet with Chinese 
President Xi Jinping to further solidify the countries' relationship.44 Calling himself a "true friend" of China,45 Najib concluded nearly $\$ 34$ billion worth of deals, including an unprecedented national defense contract to purchase four Chinese naval vessels.

Claiming to combat social unrest and political instability, the Government has also revoked the publishing license of two news outlets that reported on the corruption, threatened sanctions on social media sites that allow the spread of news, and rejected applications to protest by organizing groups.47 In advance of an August 2015 demonstration in Kuala Lumpur, Najib's Home Minister banned the group's signature yellow T-shirts carrying the word "clean" in Malay - shirts owned by tens of thousands of people, fed up with a government that has proven to be far from clean.48 On February 19, 2016, the High Court upheld the edict that declared the shirt a threat to national security.49 And prior to that ruling, on December 22, 2015, the Government passed a new National Security Council bill that gives the Government the ability to declare "security zones," within which authorities would have nearly unrestrained powers to make arrests - leaving critics fearing that political opponents will once again be targeted under the guise of national security.50 Under Najib's administration, those brave enough to criticize the regime are seldom surviving unscathed.

Recently, the Government has also been considering amending the Official Secrets Act of 1972 (OSA) as a further means of suppressing dissent. The amendments under consideration include the increased punishment of life imprisonment and ten lashes for those found guilty of leaking "state secrets." 51 The maximum current punishment is only sevenyears imprisonment. Former Attorney General Tan Sri Talib Othman has called the proposal "disproportionate to the nature of the offence," 52 and media organizations around the world have raised serious concerns. For example, the Centre for Independent Journalism issued the statement that it "is appalled at the most recent assault against the right to freedom of expression and information and its critical role in upholding democracy in Malaysia. We refer to the proposal by Attorney-General Mohamad Apandi Ali to increase the punishment under the already heavy-handed Official Secrets Act ...to target journalists."

In the wake of the opinion of the UN Working Group on Arbitrary Detention (Working Group) that Anwar is arbitrarily detained, on April 5, 2016 Malaysia's Foreign Minister Datuk Seri Anifa Aman, in a written statement in Parliament, said that Anwar did not meet the criteria to qualify as a political prisoner, claiming that his trial was free from executive and legislative interference.54 Anifah further stated that the Working Group is only comprised of five individuals and hence, its stance does not reflect that of the United Nations.55 He also reiterated that the Working Group's opinion is not legally binding.

Meanwhile, Najib has continued to bolster his grip on power and interferes with the opposition activities where possible. On May 3, 2016, Anwar's daughter, Nurul Izzah Anwar, was barred from participating in a local election campaign in the Sarawak (a semiautonomous state) and forced to leave.57 She was subjected, like many other political leaders and activists, to the ban on "unsavory elements" that was imposed a month earlier by Sarawak's Chief Minister, Mr. Adenan Satem.58 Mr. Adenan, who is also known to be a close ally of Mr. Najib, said in an interview that "there will be no lifting of the ban" but the opposition was "at liberty to come to Sarawak after the election."

Another strategy of Najib to strengthen his government is the rewarding of party loyalists. For example, on June 8, 2016, Shafee Abdullah, the Chief Prosecutor for Anwar's appeal, was appointed as Ambassador-at Large for Human Rights for a 2-year term (from 2016-2018).60 According to the Malaysian Government, this appointment is a "manifestation of ... Malaysia's firm commitment to enhance engagement in addressing human rights issues with all stakeholders, including civil society organizations (CSOs), academia, Government agencies and international organizations on human rights issues." 
This strategy also includes the removal of those less supportive to Najib. Accordingly, on June 24, 2016, Najib expelled his then-deputy Muhyiddan Yassin and Mukhriz Mahathir, son of former premier Mahathir Mohamad.62 A surprise meeting with Mahathir Mohamed and Anwar followed Najib's firing of Mahathir Mohamed's son. This was the first time the two rivals have met in 18 years; their meeting signals a potential unity in the wake of the scandaltainted and repressive administration of Najib.

In the face of mounting protest against him, Najib has most recently begun preemptively arresting opposition leaders in an attempt to suppress popular dissent. Prior to a weekend rally on November 19, 2016, which drew crowds in the tens of thousands, Najib had eight rally organizers arrested.64 They included Bersih chairwomen, Maria Chin Abdullah, who is now being held under the draconian Security Offences Act.65 Amnesty International decried the "crude and heavy-handed attempt to intimidate" and designated those arrested as prisoners of conscience who must be released immediately and unconditionally.

\section{Conclusion}

When Anwar's opposition coalition won 52 percent of the popular vote in the 2013 elections, Najib could not allow Anwar to remain free. Anwar was finally imprisoned by his judiciary last year. To maintain his grip on power, Najib has imposed severe restrictions on public protest, imprisoned countless people for exercising their basic rights of freedom of expression, and maintained almost total domination of the media.

This government has also stoked enmity between ethnic Malay Muslims on one hand, and ethnic Chinese and Indians of Christian, Buddhist, and Hindu religious affiliations on the other.

\section{References}

Editorial Board, Malaysia's Political Backslide, WASHINGTON POST, Feb. 11, 2015, available at https://www.washingtonpost.com/opinions/malaysiasreversal/2015/02/11/d116f182-b21a-11e4-827f- 93f454140e2b_story.html [hereinafter Malaysia's Political Backslide].

Phil Robertson, Anwar Imprisoned, Malaysia Rights in Free Fall, CNN, Feb. 16, 2015, available at http://www.cnn.com/2015/02/16/opinion/malaysia-anwar-human-rightswatch/ [hereinafter Robertson]. 5 What's Malay for Gerrymandering?, THE ECONOMIST, Aug. 9, 2014, available at

http://www.economist.com/news/asia/21611139-years-delineation-electoral-boundaries-willdetermine-future- malaysian-politics-whats.

Malaysia’s Political Backslide, supra note 2; Robertson, supra note 4.

Robertson, supra note 4.

Al-Zaquan Amer Hamzah, Islamic Law Debate Puts More Pressure on Malaysia PM, REUTERS, Apr. 16, 2015, available at http://www.reuters.com/article/us-malaysiapolitics-islam-idUSKBNON70BH20150416.

Malaysian PM Supports Court Ban on Non-Muslims Using the Word 'Allah,' ABC, Jan. 24, 2014, available at

http://www.abc.net.au/news/2014-01-25/malaysian-pm-razak-says-christians-must-heed27allah27- ban/5218608.

Non-Muslims in Malaysia Worry About Increasing Islamization, CCTV NEWS, Feb. 16, 2015, available at 
http://www.cctv-america.com/2015/02/16/non-muslims-in-malaysia-worry-about-increasingislamization.

Najib Stirs Up Controversy With UMNO-ISIS Comment, CHANNEL NEWS ASIA, Jun. 24, 2014, available at

http://www.channelnewsasia.com/news/specialreports/mh370/news/najib-stirsup/1200122.html; Najib has since condemned ISIS in a statement at the UN General Assembly. Statement by The Honourable Mohd Najib Tun Abdul Razak Prime Minister Of Malaysia, Sept. 26, 2014, available at http://www.un.org/en/ga/69/meetings/gadebate/pdf/MY_en.pdf.

Lurch to Illiberalism, THE ECONOMIST, Apr. 11, 2015, available at http://www.economist.com/news/asia/21648027-anti-terror-law-curtails-liberties-lurchilliberalism.

Malaysia Toughens Sedition Law to Include Online Media Ban, Mandatory Jail, REUTERS, Apr. 10, 2015, available at http://www.reuters.com/article/us-malaysia-lawmakingsedition-idUSKBNON10AD20150410. 15 Mong Palatino, Malaysia Strengthens Sedition Act, THE DIPLOMAT, Apr. 13, 2015, available at http://thediplomat.com/2015/04/malaysia-strengthens-sedition-act/.

Malaysia: Draft Anti-Terror and Sedition Laws Seriously Undermine Freedom of Expression and Opinion, OHCHR, Apr. 9, 2015, available at http://www.ohchr.org/EN/NewsEvents/Pages/DisplayNews.aspx?NewsID=15810\&Lan $\mathrm{gID}=\mathrm{E}$.

Disconnect: A Thuggish Government is Playing Racial Politics, THE ECONOMIST, Apr. 11, 2015, available athttp://www.economist.com/news/leaders/21647972-thuggishgovernment-playing-racial-politics-najib-razak- should-be-dressed-down-disconnect [hereinafter Disconnect].

Anwar Ibrahim's Daughter Arrested in Latest Move Against Malaysian Opposition, THE GUARDIAN, Mar.

2015, available at http://www.theguardian.com/world/2015/mar/16/nurul-izzah-anwar-arrestcriticised- malaysia-opposition-anwar-ibrahim.

Surendra Ananth, Section 124B: A Neutral Comment on 'Activities Detrimental to Parliamentary Democracy, MALAY MAIL ONLINE, Aug. 3, 2015 available at http://www.themalaymailonline.com/what-you- think/article/section-124b-of-the-penalcode-a-neutral-comment-on-activities-detrimental.

Section 124B of the Penal Code Must Not be Used to Curb Freedom of Assembly, Aug. 28, 2015 , available athttp://www.malaysianbar.org.my/legal/general_news/press_release_\%7C_section_12 4b_of_the_penal_code_mu st_not_be_used_to_curb_freedom_of_assembly.html.

Elizabeth Zachariah, Nurul Izzah Next to be Questioned by Cops Over Links with Justo, THE MALAYSIAN

INSIDER, Sept. 17, 2015, available at http://www.themalaysianinsider.com/malaysia/article/nurul-izzah-next-toquestioned-by-cops-over-links-with-justo.

How Najib Plans to Eliminate the Opposition, SARAWAK REPORT, Oct. 8, 2015, available athttp://www.sarawakreport.org/2015/10/how-najib-plans-to-eliminate-the-opposition/.

Malaysian State Bars Lawmaker Nurul Izzah Anwar from Campaigning, THE NEW YORK TIMES, May 3, 2015, available at http://www.nytimes.com/2016/05/04/world/asia/malaysia-sarawak-election.html?_r=0.

Austin Ramzy, Editors and Executives of News Website Malaysian Insider Are Arrested, NEW YORK TIMES, 
Mar. 31, 2015, available at http://www.nytimes.com/2015/04/01/world/asia/malaysianinsider-arrests.html.

Malaysian Cartoonist Zunar Charged With Nine Counts of Sedition, WALL STREET JOURNAL, Apr. 3, 2015, available at http://www.wsj.com/articles/malaysiancartoonist-zunar-charged-with-nine-counts-of-sedition- 1428040017.

Tarrence Tan, The Malaysian Insider Blocked by MCMC, FREE MALAYSIA TODAY, Feb. 25, 2016, available at http://www.freemalaysiatoday.com/category/nation/2016/02/25/the-malaysian-insiderblocked-by-mcmc/..

Yantoultra Ngui, Malaysian Insider to Close After Government Blocked It Following 1MDB Coverage, WALL STREET JOURNAL, Mar. 14, 2016, available at http://www.wsj.com/articles/malaysian-insider-news-site-closing- 1457942708.

Disconnect, supra note 18; More Smear Tactics and Black Ops by Najib's PR Hit Team, SARAWAK REPORT,

May 12, 2015, available at http://www.sarawakreport.org/2015/05/more-smear-tactics-andblack-ops-by-najibs- pr-hit-team-anwar-and-dr-m-both-targets-exclusive/ [hereinafter More Smear Tactics].

How Najib Plans to Eliminate the Opposition, supra note 24.

Eileen Ng, Malaysian Leader Silences Critics, Media to Survive Scandal, ASSOCIATED PRESS, Aug. 16, 2015, available athttp://bigstory.ap.org/article/ea6760c46ddc4a74baf01e3af17d680e/malaysian-leadersilences- critics-media-survive-scandal.

Malaysia PM Najib Razak Sacks Deputy Over 1MDB Scandal, BBC, July 28, 2015, available at http://www.bbc.com/news/world-asia-33684987.

How Najib Plans to Eliminate the Opposition, supra note 24.

Tom Wright \& Bradley Hope, 1MDB Probe Shows Malaysian Leader Najib Spent Millions on Luxury Goods, WALL STREET JOURNAL, Mar. 30, 2016, available at http://www.wsj.com/articles/malaysian-leader-spent- millions-on-luxury-goods1459383835.

Bradley Hope \& Tom Wright, Malaysian Leader Najib's Stepson Allegedly Funded U.S. Property Deals with

1MDB Money, WALL STREET JOURNAL, May 4, 2016, available at http://www.wsj.com/articles/malaysian- leader-najibs-stepson-allegedly-funded-u-sproperty-deals-with-1mdb-money-1463022324.

Shannon Teoh, 1MDB Parliamentary Probe Blames ex-CEO; Board of Directors Resign, THE STRAITS TIMES,

April 7, 2016, available at http://www.straitstimes.com/asia/se-asia/malaysias-parliamentarypanel-blames- founding-chief-executive-for-1mdb-woes; see also Yantoultra Ngui, Malaysia to Dissolve 1MDB Board Headed by Prime Minister Najib Razak, WALL STREET JOURNAL, May 4, 2016, available at

Hanis Maketab, Malaysian Journalists Criticize Proposal to Increase Punishment for Whistleblowers, ASIAN CORRESPONDENT, Feb. 10, 2016, available at https://asiancorrespondent.com/2016/02/malaysian-journalists- criticize-proposal-toincrease-punishment-for-whistleblowers/.

Anisah Shukry, Punishment for Whistleblowers Uncalled for, Says Former A-G, THE MALAYSIAN INSIDER,

Feb. 9, 2016, available at http://www.themalaysianinsider.com/malaysia/article/punishmentfor-whistleblowers- uncalled-for-says-former-a-g. 
CENTRE FOR INDEPENDENT JOURNALISM, CIJ Condemns A-G's Proposal for Heavier Punishment for

Journalists, Informants, Feb. 6, 2016, available at https://www.facebook.com/notes/centrefor-independent- journalism/cij-condemns-ags-proposal-for-heavier-punishment-forjournalists-informants/1249746521707336. 54 Koi Kye Lee, Anwar Ibrahim Doesn't Meet 'Political Prisoner' criteria, NEW STRAITS TIMES ONLINE, April 5, 2016, available at http://www.nst.com.my/news/2016/04/137438/anwar-ibrahim-doesnt-meetpolitical- prisoner-criteria.

Richard C. Paddock, Malaysian State Bars Lawmaker Nurul Izzah Anwar From Campaigning, THE NEW YORK TIMES, May 3, 2016, available at http://www.nytimes.com/2016/05/04/world/asia/malaysia-sarawak- election.html?_r=0.

Peter Sibon, Lian Chenc and Karen Bong, CM: It's Our Right to Bar Unsavoury Characters from Entering Sarawak, BORNEO POST ONLINE, April 13, 2016, available at http://www.theborneopost.com/2016/04/13/cm- its-our-right-to-bar-unsavourycharacters-from-entering-sarawak/.

Press Releaes: Appointment of Ambassador-At-Large for Human Rights, MINISTRY OF FOREIGN AFFAIRS PUTRAJAYA, June 8, 2016, available at http://bit.ly/1U963B6.

Unmo Lawyer Shafee Appointed Malaysia's Human Rights Envoy, MALAYMAIL ONLINE, June 9, 2016, available at http://www.themalaymailonline.com/malaysia/article/umno-lawyer-shafee-appointedmalaysias- human-rights-envoy.

Pooi Koon Chong and Manirajan Ramasamy, Najib Rewards Party Loyalists in Malaysia Cabinet Rejig, BLOOMBERG, June 27, 2016, available at http://www.bloomberg.com/news/articles/2016-06-27/najib-rewards- loyalists-inmalaysia-cabinet-rejig-amid-tensions.

Joseph Sipalan, Malaysia's Mahathir and bitter foe Anwar shake hands in first meeting after 18 years,

REUTERS, Sept. 5, 2016, available at http://www.reuters.com/article/us-malaysia-politicsmahathir- idUSKCN11B1BB.

Richard Paddock, Tens of Thousand of Protesters Call for Najib Razak, Malaysian Leader, to Resign, New

York Times, Nov. 19, 2016, available at http://www.nytimes.com/2016/11/20/world/asia/tens-of-thousands-of- protesters-callfor-najib-razak-malaysian-leader-to-resign.html.

Malaysia: End Crackdown on Bersih Activists, AMNESTY INT'L, Nov. 18, 2016, available at https://www.amnesty.org/en/latest/news/2016/11/malaysia-end-crackdown-onbersih-activists/. 67 Profile: Anwar Ibrahim, AL JAZEERA, May 6, 2013, available athttp://www.aljazeera.com/indepth/spotlight/malaysiaelections/2013/05/20135112593 4750972.html. 